\title{
Effects of Organic and Inorganic Fertilizers on Yield and Yield Contributing Characters of Mukhi Kachu (Colocasia esculenta L.)
}

\author{
D. Hossain ${ }^{1}$, M. Ullah ${ }^{2}$ M. Shahjahan ${ }^{3}$, M. A Haque ${ }^{4 *}$ and M. Ali ${ }^{5}$ \\ Depts. of Soil Science ${ }^{1}$ and Horticulture ${ }^{5}$, Patuakhali Science and Technology University, Bangladesh \\ ${ }^{2}$ OFRD, Bangladesh Agricultural Research Institute, Gazipur-1701, Bangladesh \\ ${ }^{3}$ Bangladesh Agricultural Research Council, Dhaka, Bangladesh \\ ${ }^{4}$ Department of Biotechnology, BSMRAU, Gazipur-1706, Bangladesh \\ *Corresponding author: ashrafbiotech@gmail.com
}

\begin{abstract}
The response of mukhi kachu (Colocasia esculenta L.) cultivars (Bilashi and local variety) to inorganic (Urea $140 \mathrm{~kg} \mathrm{ha}^{-1}$, TSP $=95 \mathrm{~kg} \mathrm{ha}^{-1}, \mathrm{MP}=145 \mathrm{~kg} \mathrm{ha}^{-1}$ and Urea $150 \mathrm{~kg} \mathrm{ha}^{-1}, \mathrm{TSP}=100 \mathrm{~kg}$ $\mathrm{ha}^{-1}, \mathrm{MP}=150 \mathrm{~kg} \mathrm{ha}^{-1)}$ and organic (Cowdung 5,000 kg ha ${ }^{-1}$ Mustard oil cake $100 \mathrm{~kg} \mathrm{ha}^{-1}$ and Poultry dropping $8000 \mathrm{~kg} \mathrm{ha}^{-1}$ ) fertilizers was determined at the farm of Patuakhali Science and Technology University, Bangladesh. Different levels of organic and inorganic fertilizers showed significant effect on number of cormels, dry weight of cormels and yield of the crop. Organic fertilizers produced significantly higher yields of mukhi kachu over the inorganic fertilizers. The variety Bilashi produced the highest yield $\left(25.66 \mathrm{t} \mathrm{ha}^{-1}\right)$ with the application of mustard oil cake.
\end{abstract}

Keywords: Mukhi kachu, cormels, plant growth, yield, organic fertilizer, inorganic fertilizer.

\section{Introduction}

Mukhi kachu (Colocasia esculenta L.) is a popular indigenous vegetable and the most widely cultivated edible aroid in Bangladesh. The crop is extensively grown in the kharif season and it can contribute considerably part to the total supply of bulky vegetables during the late summer when other vegetables are scarce in the market (Ahmed and Rashid, 1975). It is grown all over the country but commercially cultivated in Chittagong, Bogra, Sylhet and Pabna districts of Bangladesh (Rashid, 1993).

A number of mukhi kachu varieties have been released by different research organizations in Bangladesh but the influence of organic and inorganic fertilizer on their performance has not been tested. Application of chemical fertilizers may increase its yield. But the imbalanced and excess use of chemical fertilizers degrades the soil and the environment (Higa, 1991). The over application of chemical fertilizers and pesticides has caused pollution of soil, water and air which has adversely affected food safety and quality and has endangered human and animal health (Matsumoto, 1994).

Cultivation of mukhi kachu using organic fertilizer is less expensive than that of chemical fertilizers. The present investigation was therefore, carried out to evaluate the response of yield and yield contributing characters of mukhi kachu to applied mustard oil cake, cowdung, poultry litters and fertilizer.

\section{Materials and Methods}

The experiment was conducted at the research farm of Patuakhali Science and Technology University, Bangladesh to study the effects of mustard oil cake, cowdung, poultry litters and chemical fertilizers on plant height, number of leaves, leaf area index, fresh weight of leaves, fresh weight of roots and total biomass, number 
of cormels, weight of cormels and yield of mukhi kachu. Cormels are used as seed in this experiment. The soil of the study area belongs to Ganges Tidal Flood plain (FAO-UNDP, 1988). The collected soil samples were air -dried, ground and passed through a 20 mesh sieve. The soil was of silty loam having $\mathrm{pH} 6.8$, organic carbon $0.80 \%$, CEC 13 meq/100 g soil, available nitrogen $0.06 \%$, available P 10.90 ppm, K 6.98 meq/100 g soil, S $12.70 \mathrm{ppm}$, exchangeable $\mathrm{Ca}$ $5.98 \mathrm{meq} / 100 \mathrm{~g}$ soil.

The experiment was laid out in a split plot design with 3 replications. The two varieties of mukhi kachu were Bilashi and local and the sources of nutrients (organic and inorganic). The six source of nutrients were: i) Control ii) Urea $140 \mathrm{~kg}$, TSP $95 \mathrm{~kg}$ and MP $145 \mathrm{~kg} \mathrm{ha}^{-1}$; ii) Urea $150 \mathrm{~kg}$, TSP $100 \mathrm{~kg}$; and MP $150 \mathrm{~kg} \mathrm{ha}^{-1}$ iii) Cowdung 5,000 $\mathrm{kg} \mathrm{ha}^{-1}$; iv) Mustard oil cake $100 \mathrm{~kg} \mathrm{ha}^{-1}$; and vi) Poultry litters $8000 \mathrm{~kg} \mathrm{ha}^{-1}$. The full dose of TSP, MP, cowdung, decomposed poultry litters and half dose of urea were applied at the time of final land preparation and rest half of urea was top dressed at 60 and 80 days after transplanting of the crop. Mustard oil cake was decomposed for 10 days by adding tap water. It was mixed with $50 \mathrm{~g}$ urea, $100 \mathrm{~g}$ TSP and $80 \mathrm{~g} \mathrm{MP} \mathrm{kg}^{-1}$ and then applied at 60 days after planting at the rhizosphere zone of the crop.

There were 36 plots and unit plot size was $4 \mathrm{~m} \times$ $2 \mathrm{~m}$. Plant samples were collected at 90, 120 and 150 days after planting for growth analysis and the final harvest was done at 180 days after planting. There were 14 plants left per plot for the final harvest. The recorded data on various characters of the crop were statistically analyzed to determine out the significance of variation resulting from the treatments. The differences between the treatment means were compared by Duncan's Multiple Range Test (DMRT).

\section{Results and Discussion} 3.1. Plant height

The maximum plant height of the local varieties of mukhi kachu was found where mustard oil cake was applied (Table1). The control treatment produced the shortest plants of both the varieties. Plant height gradually declined after reaching maximum height at 90 days after planting. The reduction might have caused due to the death of older leaves. Ali et al. (2000) recorded the maximum plant height of mukhi kachu at 90 days after planting the cormels while Dhar (1989) observed the maximum plant height at 114 days after planting. Inorganic and organic fertilizers did not influence plant height.

\subsection{Number of leaves and leaf area index}

The number of leaves per plant was counted at maximum vegetative stage at 90 days after planting (Table 1). The variety Bilashi gave the maximum number of leaves (5.60 plant $\left.^{-1}\right)$ in the plots treated with mustard oil cake, where as the local variety produced the lowest number of leaves (3.26 plant $\left.^{-1}\right)$ in the control plot. Bhuyan et at. (1982) found the maximum number of leaves (3.53 plant $^{-1}$ ) at 180 days after planting. Organic and inorganic fertilizers did not show any significant effect on number of leaves per plant.

The maximum leaf area index in all the cases of inorganic fertilizers, cowdung and mustard oil cake reached at 90 days after planting (Table 1). The leaf area index of the variety Bilashi was found maximum (5.00) in plots treated with mustard oil cake and minimum (1.50) in the control plot. In all cases however, the leaf area index decreased from 90 days after planting, which was presumably due to senescence of the older leaves. Ali et al. (2000) observed the maximum leaf area index of mukhi kachu at 90 days after planting. There was no significant effect of organic and inorganic fertilizers on leaf area index. 
Table 1. Effect of different sources of nutrients on the plant height, number of leaves and leaf area index of mukhi kachu at different days after planting.

\begin{tabular}{|c|c|c|c|c|c|c|c|c|c|}
\hline \multirow{2}{*}{ Variety } & \multirow{2}{*}{ Treatment } & \multicolumn{4}{|c|}{ Plant height $\left(\mathrm{cm} \mathrm{plant}^{-1}\right)$} & \multirow{2}{*}{$\begin{array}{c}\begin{array}{c}\text { No. of } \\
\text { leaves } \\
\text { plant }^{-1}\end{array} \\
90 \\
\text { DAP } \\
\end{array}$} & \multicolumn{3}{|c|}{ Leaf area index } \\
\hline & & 60 DAP & 90 DAP & $\begin{array}{c}120 \\
\text { DAP }\end{array}$ & $\begin{array}{c}150 \\
\text { DAP }\end{array}$ & & $\begin{array}{c}90 \\
\text { DAP }\end{array}$ & $\begin{array}{c}120 \\
\text { DAP }\end{array}$ & $\begin{array}{c}150 \\
\text { DAP }\end{array}$ \\
\hline \multirow[t]{6}{*}{ Bilashi } & Control & 55.14 & 70.54 & 68.16 & 66.00 & 3.83 & 2.43 & 1.70 & 1.50 \\
\hline & $\mathrm{I}_{1}$ & 71.10 & 75.55 & 71.22 & 70.00 & 4.16 & 4.30 & 3.13 & 2.73 \\
\hline & $\mathrm{I}_{2}$ & 73.00 & 78.57 & 73.82 & 72.33 & 4.63 & 4.60 & 3.20 & 2.76 \\
\hline & $\mathrm{O}_{1}$ & 72.00 & 75.26 & 74.55 & 73.00 & 4.96 & 4.90 & 4.30 & 3.30 \\
\hline & $\mathrm{O}_{2}$ & 73.76 & 78.54 & 77.19 & 76.00 & 5.60 & 5.00 & 4.50 & 3.86 \\
\hline & $\mathrm{O}_{3}$ & 60.07 & 71.90 & 70.15 & 69.02 & 4.06 & 3.60 & 3.00 & 2.53 \\
\hline \multirow[t]{6}{*}{ Local } & Control & 60.07 & 70.88 & 68.90 & 67.12 & 3.26 & 2.43 & 2.10 & 2.00 \\
\hline & $\mathrm{I}_{1}$ & 74.81 & 75.86 & 72.21 & 71.66 & 4.00 & 3.06 & 3.00 & 2.50 \\
\hline & $\mathrm{I}_{2}$ & 75.27 & 80.99 & 76.89 & 73.66 & 4.26 & 4.05 & 4.00 & 3.50 \\
\hline & $\mathrm{O}_{1}$ & 70.10 & 82.19 & 77.99 & 74.33 & 4.50 & 4.10 & 3.60 & 3.46 \\
\hline & $\mathrm{O}_{2}$ & 78.10 & 85.52 & 83.20 & 82.66 & 5.10 & 4.80 & 4.63 & 3.90 \\
\hline & $\mathrm{O}_{3}$ & 65.13 & 71.17 & 69.18 & 68.66 & 3.90 & 3.50 & 3.30 & 2.80 \\
\hline $\operatorname{LSD}_{(0.05)}$ & & NS & NS & NS & NS & NS & NS & NS & NS \\
\hline
\end{tabular}

Means in a column followed by same letter (s) are not significantly different at 5\% level of DMRT

NS- Non significant, DAP- Days after planting, $\mathrm{I}_{1}$ - Urea $140 \mathrm{~kg} \mathrm{ha}^{-1}$, TSP- $95 \mathrm{~kg} \mathrm{ha}^{-1}$, MP- $145 \mathrm{~kg} \mathrm{ha}^{-1}, \mathrm{I}_{2}-$ Urea $150 \mathrm{~kg} \mathrm{ha}^{-1}$, TSP- $100 \mathrm{~kg} \mathrm{ha}^{-1}$, MP- $150 \mathrm{~kg} \mathrm{ha}^{-1}$ (Recommended dose for the soils of Bangladesh), $\mathrm{O}_{1}$ - Cowdung$5,000 \mathrm{~kg} \mathrm{ha}^{-1}, \mathrm{O}_{2}$ - Mustard oil cake- $100 \mathrm{~kg} \mathrm{ha}^{-1}, \mathrm{O}_{3}$-Poultry liter $-800 \mathrm{~kg} \mathrm{ha}^{-1}$.

\subsection{Biomass production}

The fresh weight of leaves per plant of the local variety at 90 days after transplanting was found maximum (77.85 $\left.\mathrm{g} \mathrm{plant}^{-1}\right)$ in the mustard oil cake treated plot (Table 2). There was no significant difference in the weight of leaves per plant among mustard oil cake, cowdung and fertilizer. After the maximum vegetative growth stage (90 DAP), the weight of leaves was gradually declining. This was due to leaf senescence. The fresh weight was found maximum (89.38 g) in plots receiving cowdung (Ali, 1996).

The effect of organic and inorganic fertilizers on fresh weight of roots of mukhi kachu was found significant (Table 2). At the maximum growth stage, the amount of roots of the variety Bilashi in poultry liter treated plot was $78.14 \mathrm{~g} \mathrm{hill}^{-1}$, whereas it was $70.17 \mathrm{~g} \mathrm{hill}^{-1}$ in the control plot. Using cowdung as a nutrient source the maximum fresh weight of roots $\left(116.68 \mathrm{~g} \mathrm{hill}^{-1}\right)$ was found in Bilashi compared to the local variety of mukhi kachu (Ali, 1996). As with the leaves, root weight sharply declined after the maximum growth stage at 90 days after planting. Such a decline in root weight might occur from reduced supply of photosynthates from the declining leaf area.

Total biomass production of mukhi kachu was insignificantly influenced by organic and inorganic fertilizers. The highest biomass 
(175.26 $\mathrm{g} \mathrm{plant}^{-1}$ ) was produced by Bilashi treated with mustard oil cake and reached the peak at 150 days after planting. Through out the growing period of Bilashi, mustard oil cake was superior to fertilizer, cowdung, poultry dropping and control.

The total biomass produced by Bilashi and local variety of mukhi kachu using mustard oil cake were 175.26 and $151.89 \mathrm{~g}$ per plant at 150 days after planting, respectively. But total biomss production at plots with mustard oil cake with the combination of Bilashi and local variety reached the peak at 180 days after planting, indicating a slow initial growth of the plants. Ali (1996) reported that cowdung increased total biomass as compared to inorganic fertilizer, poultry dropping and control in Bilashi. Total biomass was very weakly correlated with the number of cormels, weight of cormels and yield of the crop at the different days after planting (Table 4). However, total biomass was significantly correlated with weight of cormels at different dates $(r=0.31 *)$.

Table 2. Effect of different sources of nutrients on the fresh weight of leaves, fresh weight of roots and total biomass of mukhi kachu at different days after planting.

\begin{tabular}{|c|c|c|c|c|c|c|c|c|c|c|c|c|}
\hline \multirow{2}{*}{ Variety } & \multirow{2}{*}{$\begin{array}{c}\text { Treatme } \\
\text { nt }\end{array}$} & \multicolumn{3}{|c|}{$\begin{array}{l}\text { Fresh weight of leaves } \\
\left(\mathrm{g} \mathrm{plnat}^{-1}\right)\end{array}$} & \multicolumn{4}{|c|}{$\begin{array}{l}\text { Fresh weight of roots } \\
\left(\mathrm{g} \mathrm{hill}^{-1}\right)\end{array}$} & \multicolumn{4}{|c|}{ 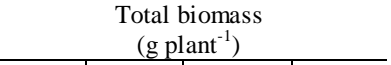 } \\
\hline & & $\begin{array}{c}90 \\
\text { DAP }\end{array}$ & $\begin{array}{l}120 \\
\text { DAP }\end{array}$ & $\begin{array}{l}150 \\
\text { DAP }\end{array}$ & $\begin{array}{l}90 \\
\text { DAP }\end{array}$ & $\begin{array}{l}120 \\
\text { DAP }\end{array}$ & $\begin{array}{l}150 \\
\text { DAP }\end{array}$ & $\begin{array}{l}180 \\
\text { DAP }\end{array}$ & $\begin{array}{l}90 \\
\text { DAP }\end{array}$ & $\begin{array}{l}120 \\
\text { DAP }\end{array}$ & $\begin{array}{l}150 \\
\text { DAP }\end{array}$ & $\begin{array}{l}180 \\
\text { DAP }\end{array}$ \\
\hline \multirow{4}{*}{ Bilashi } & Control & 65.18 & 45.21 & 29.56 & 70.17 & 65.63 & 58.48 & 48.49 & 43.54 & 80.18 & 130.91 & 125.32 \\
\hline & $I_{1}$ & 71.87 & 49.45 & 35.51 & 90.24 & 88.48 & 80.16 & 73.50 & 50.34 & 93.25 & 136.91 & 135.16 \\
\hline & $\mathrm{I}_{2}$ & 76.27 & 52.29 & 37.69 & 90.24 & 87.75 & 81.87 & 73.55 & 53.85 & 99.29 & 150.58 & 145.58 \\
\hline & $\mathrm{O}_{1}$ & 74.87 & 50.18 & 36.19 & 94.89 & 89.61 & 81.92 & 75.35 & 57.49 & 100.27 & 154.50 & 148.91 \\
\hline & $\mathrm{O}_{2}$ & 77.52 & 55.19 & 40.22 & 100.13 & 93.69 & 90.57 & 82.62 & 60.26 & 111.91 & 175.26 & 170.27 \\
\hline & $\mathrm{O}_{3}$ & 70.80 & 48.27 & 32.20 & 78.14 & 70.23 & 61.84 & 52.02 & 48.36 & 85.20 & 146.92 & 140.25 \\
\hline \multirow[t]{6}{*}{ Local } & Control & 72.32 & 46.57 & 30.54 & 78.24 & 70.24 & 62.03 & 53.56 & 48.22 & 81.94 & 126.24 & 125.85 \\
\hline & $\mathrm{I}_{1}$ & 76.27 & 48.19 & 36.25 & 100.03 & 90.39 & 85.19 & 80.49 & 51.23 & 83.57 & 146.91 & 136.02 \\
\hline & $\mathrm{I}_{2}$ & 77.19 & 52.21 & 37.52 & 105.34 & 94.71 & 93.74 & 86.92 & 53.33 & 85.61 & 137.57 & 130.94 \\
\hline & $\mathrm{O}_{1}$ & 70.97 & 51.55 & 37.19 & 92.50 & 92.03 & 82.03 & 83.00 & 54.52 & 86.97 & 150.25 & 141.23 \\
\hline & $\mathrm{O}_{2}$ & 77.85 & 57.87 & 42.18 & 100.17 & 95.23 & 90.49 & 83.54 & 61.95 & 95.29 & 151.89 & 148.58 \\
\hline & $\mathrm{O}_{3}$ & 74.91 & 49.23 & 32.81 & 88.24 & 83.84 & 77.15 & 66.82 & 57.98 & 85.58 & 142.66 & 140.93 \\
\hline $\operatorname{LSD}_{(0.05)}$ & & NS & NS & NS & NS & NS & NS & NS & NS & NS & NS & NS \\
\hline
\end{tabular}

Means in a column followed by same letter (s) are not significantly different at 5\% level of DMRT

NS- Non significant, DAP- Days after planting, $\mathrm{I}_{1}$ - Urea $140 \mathrm{~kg} \mathrm{ha}^{-1}$, TSP- $95 \mathrm{~kg} \mathrm{ha}^{-1}$, MP- $145 \mathrm{~kg} \mathrm{ha}^{-1}, \mathrm{I}_{2}$. Urea $150 \mathrm{~kg} \mathrm{ha}^{-1}$, TSP- $100 \mathrm{~kg} \mathrm{ha}^{-1}$, MP- $150 \mathrm{~kg} \mathrm{ha}^{-1}$ (Recommended dose for the soils of Bangladesh), $\mathrm{O}_{1}$ - Cowdung$5,000 \mathrm{~kg} \mathrm{ha}^{-1}, \mathrm{O}_{2}$ - Mustard oil cake- $100 \mathrm{~kg} \mathrm{ha}^{-1}, \mathrm{O}_{3}$-Poultry liter - $800 \mathrm{~kg} \mathrm{ha}^{-1}$. 


\subsection{Number and weight of cormels}

The variety had a significant positive interaction on number of cormels at various days after planting. The number of cormels per hill increased progressively upto 180 days after planting irrespective of the source of nutrients. The variety Bilashi with mustard oil cake produced the highest number of cormels $\left(22.47\right.$ hill $\left.^{-1}\right)$ which was significantly different from the number of cormels obtained using fertilizers. The local variety produced the lowest number of cormels in control plots. Ali et al. (2000) found that Bilashi gave the maximum number of cormels of 16.96, 24.92 and 35.37 per hill at 120,150 and 180 days after planting, respectively when cowdung was applied as a source of nutrient.

The interaction effects of variety and organic, inorganic fertilizers on the weight of cormels was significant at different growth stages of the crop (Table 3). The maximum weight of cormels (320.20 $\mathrm{g} \mathrm{hill}^{-1}$ ) was achieved at 180 days after planting by Bilashi with the combination of mustard oil cake and the effect of this treatment was statistically superior to the interaction effect of cowdung and recommended fertilizer with the association of the variety Bilashi in most of the cases of source of nutrients. Poultry liters and control with both the varieties viz. Bilashi and local produced significantly lower weight of cormels than mustard oil cake, cowdung and fertilizers. Poultry liters was superior to control plot in all the sampling dates from 120 to 180 days after planting. Ali et al. (2000) illustrated that cowdung produced the maximum weight of cormels of Bilashi. In the present study, weight of cormels had a positive correlation with total biomass at the different days after planting (Table 4).

Table 3. Effect of different sources of nutrients on the number of cormels, weight of cormels and yield of mukhi kachu at different days after planting

\begin{tabular}{|c|c|c|c|c|c|c|c|c|}
\hline \multirow[b]{2}{*}{ Variety } & \multirow[b]{2}{*}{ Treatment } & \multicolumn{3}{|c|}{ Number of cormels hill ${ }^{-1}$} & \multicolumn{3}{|c|}{ Weight of cormels $\left(\mathrm{g}\right.$ hill $\left.^{-1}\right)$} & \multirow{2}{*}{$\begin{array}{l}\text { Yield } \\
\left(\mathrm{t} \mathrm{ha}^{-1}\right)\end{array}$} \\
\hline & & $\begin{array}{c}120 \\
\text { DAP }\end{array}$ & $\begin{array}{c}150 \\
\text { DAP }\end{array}$ & $180 \mathrm{DAP}$ & 120 DAP & $150 \mathrm{DAP}$ & $\begin{array}{c}180 \\
\text { DAP }\end{array}$ & \\
\hline \multirow[t]{6}{*}{ Bilashi } & Control & $10.15 \mathrm{def}$ & $11.91 \mathrm{de}$ & $11.47 \mathrm{de}$ & $130.00 \mathrm{de}$ & 134.30de & $138.70 \mathrm{~h}$ & $9.83 \mathrm{de}$ \\
\hline & $\mathrm{I}_{1}$ & $15.10 \mathrm{bc}$ & $15.18 \mathrm{ab}$ & $17.24 \mathrm{bc}$ & $235.10 b c$ & $240.30 \mathrm{bc}$ & $245.10 \mathrm{c}$ & $16.66 \mathrm{~b}$ \\
\hline & $\mathrm{I}_{2}$ & $17.16 \mathrm{ab}$ & $17.56 \mathrm{ab}$ & $19.28 \mathrm{ab}$ & $279.80 \mathrm{ab}$ & $284.60 \mathrm{ab}$ & $288.70 b$ & $18.34 \mathrm{~b}$ \\
\hline & $\mathrm{O}_{1}$ & $18.52 \mathrm{ab}$ & $19.45 b c$ & $20.22 \mathrm{ab}$ & $280.00 \mathrm{ab}$ & $286.40 \mathrm{ab}$ & $291.80 b$ & $19.17 \mathrm{~b}$ \\
\hline & $\mathrm{O}_{2}$ & $20.90 \mathrm{a}$ & $21.93 \mathrm{a}$ & $22.47 \mathrm{a}$ & $310.10 \mathrm{a}$ & $315.10 \mathrm{a}$ & $320.20 \mathrm{a}$ & $25.66 \mathrm{a}$ \\
\hline & $\mathrm{O}_{3}$ & $12.26 \mathrm{cde}$ & $12.11 \mathrm{cde}$ & $13.47 \mathrm{cde}$ & $156.40 \mathrm{de}$ & 160.10de & $164.50 \mathrm{f}$ & $11.91 \mathrm{~cd}$ \\
\hline \multirow[t]{6}{*}{ Local } & Control & $4.11 \mathrm{~h}$ & $5.16 \mathrm{~g}$ & $4.66 \mathrm{~g}$ & $92.00 \mathrm{e}$ & $96.80 \mathrm{e}$ & $101.70 \mathrm{i}$ & $6.09 \mathrm{f}$ \\
\hline & $\mathrm{I}_{1}$ & $7.75 f g h$ & 7.83efg & $8.40 \mathrm{efg}$ & 130.10de & $135.20 \mathrm{de}$ & $139.50 \mathrm{~h}$ & 7.77ef \\
\hline & $\mathrm{I}_{2}$ & $10.12 \mathrm{~cd}$ & $10.77 \mathrm{~cd}$ & 9.73def & $137.00 \mathrm{de}$ & $140.60 \mathrm{de}$ & $144.40 \mathrm{~g}$ & $9.00 \mathrm{de}$ \\
\hline & $\mathrm{O}_{1}$ & $8.75 \mathrm{efg}$ & 10.40def & $11.83 \mathrm{de}$ & 166.70de & $171.90 \mathrm{~d}$ & $177.20 \mathrm{e}$ & $9.77 \mathrm{de}$ \\
\hline & $\mathrm{O}_{2}$ & $10.84 \mathrm{def}$ & $11.38 \mathrm{de}$ & $14.22 \mathrm{~cd}$ & $191.70 \mathrm{~cd}$ & $196.80 \mathrm{~cd}$ & $200.70 d$ & $13.07 \mathrm{c}$ \\
\hline & $\mathrm{O}_{3}$ & $5.33 \mathrm{gh}$ & $6.09 \mathrm{fg}$ & $5.66 \mathrm{fg}$ & $96.00 \mathrm{e}$ & $99.20 \mathrm{e}$ & $102.00 \mathrm{i}$ & $6.60 \mathrm{f}$ \\
\hline $\mathrm{CV}(\%)$ & & 4.56 & 6.25 & 5.36 & 5.06 & 5.62 & 4.23 & 4.01 \\
\hline
\end{tabular}

Means in a column followed by same letter (s) are not significantly different at $5 \%$ level of DMRT

DAP- Days after planting, $\mathrm{I}_{1}$ - Urea $140 \mathrm{~kg} \mathrm{ha}^{-1}$, TSP- $95 \mathrm{~kg} \mathrm{ha}^{-1}$, MP- $145 \mathrm{~kg} \mathrm{ha}^{-1}, \mathrm{I}_{2}$-- Urea $150 \mathrm{~kg} \mathrm{ha}^{-1}$, TSP- 100 $\mathrm{kg} \mathrm{ha}^{-1}, \mathrm{MP}-150 \mathrm{~kg} \mathrm{ha}^{-1}$ (Recommended dose for the soils of Bangladesh), $\mathrm{O}_{1^{-}}$Cowdung-5,000 kg ha ${ }^{-1}, \mathrm{O}_{2^{-}}$ Mustard oil cake- $100 \mathrm{~kg} \mathrm{ha}^{-1}, \mathrm{O}_{3}$-Poultry liter $-800 \mathrm{~kg} \mathrm{ha}^{-1}$. 
Table 4. Relationship between different characters of mukhi kachu at different days after planting.

\begin{tabular}{lc}
\hline \multicolumn{1}{c}{ Factors } & Correlation Co-efficient ( r) \\
\hline Total biomass vs. number of cormels at 120 days after planting & $0.041^{*}$ \\
Total biomass vs. number of cormels at 150 days after planting & $0.025^{*}$ \\
Total biomass vs. number of cormels at 180 days after planting & $0.043^{*}$ \\
Total biomass vs. weight of cormels at 120 days after planting & $0.316^{*}$ \\
Total biomass vs. weight of cormels at 150 days after planting & $0.315^{*}$ \\
Total biomass vs. weight of cormels at 180 days after planting & $.0 .314^{*}$ \\
Total biomass vs. yield of cormels & $0.168^{*}$ \\
\hline
\end{tabular}

$\mathrm{N}=36, *$ Significant at $5 \%$ level of probability

\subsection{Yield of cormels}

From Table 3, it is observed that yield of cormels $\left(25.66 \mathrm{t} \mathrm{ha}^{-1}\right)$ was increased significantly due to the application of mustard oil cake with the association of the variety Bilashi. The second highest yield (19.17 $\left.\mathrm{t} \mathrm{ha}^{-1}\right)$ was produced by Bilashi $\times$ cowdung which was statistically similar to Bilshi with inorganic fertilizer. Poultry liters produced lower yield of cormels than these treatment but was superior to control. Dhar (1989) also found the highest yield of cormels $32.44 \mathrm{t} \mathrm{ha}^{-1}$ at 216 days after planting. Ruiz et al. (1989) observed that nitrogen $350 \mathrm{t} \mathrm{ha}^{-1}$ gave the highest yield of cormels $\left(43.73 \mathrm{t} \mathrm{ha}^{-1}\right)$. The plot treated with mustard oil cake gave the highest yield than those with cowdung, two doses of fertilizers, poultry dropping and control. The highest yield has achieved due to increased leaf area index, which might have occured by the absorption of more sunlight leading to the production and supply of more photosynthates. The local variety gave the lowest yield in all treatments. Table 4 shows that the total biomass was positively but weakly correlated with the yield of cormels of the crop $\left(r=0.168^{*}\right)$.

\section{Conclusions}

Organic and inorganic fertilizers significantly influenced the yields of the two varieties of mukhi kachu. Mustard oil cake was more effective in producing cormels and yields of mukhi kachu than inorganic fertilizers. The variety Bilashi was superior in respect of yield when grown with mustard oil cake.

\section{References}

Ahmed, G. and Rashid, M.M. 1975. A comparative study on gross morphological characters and yield potentialities of the major types of edible aroids of Bangladesh. Bangladesh Horiculture, 3(1): 15-21.

Ali, M. 1996. Growth and yield of mukhi kachu (Colocasia esculenta L.) as influenced by soil amendments. M.S. Thesis. BSMRAU.

Ali, M., Chowdhury, A.R. Hossain, A.R. Haider, M.M. and Hossain, D. 2000. Effect of soil amendments on the growth and yield of mukhi kachu (Colocasia esculenta L.) Bangladesh Journal of Environmental Scence, 6: 112-117.

Bhuyan, M.A.J., Hoque, M.M. and Hoque, K.R. 1982. Effect of seed size and spacing on the yield of mukhi kachu. Bangladesh Horticulture, 10(2): 5-8.

Coursey, D.C. and Hayness, P.H. 1970. Root crops and their potentialities as food in the Tropics. World crops. 22: 261-265. 
Dhar, M. 1989. Effect of plant spacing and system of planting on the growth and yield of mukhi kachu. M.Sc. Thesis. Bangladesh Agricultural University, Mymensingh.

FAO-UNDP. 1988. Land resources appraisal of Bangladesh for agricultural development. Report No. 2. Agroecological regions of Bangladesh. 275.

Higa, T. 1991. Effective Microorganisms. A biotechnology for mankind. Presented in the $2^{\text {nd }}$ Int. conference on Kyusei Nature Farming at the Univ. Sao Paulo, College of Agric. 7-13.

Matsumoto, Y.R. 1994. Principles of Kyusie nature Farming. In J.F. Parr, S.B. Hornick and M.E. Simpson (ed). Proceedings $2^{\text {nd }}$ Int. Conference on Kyusei Nature Farming. 3-4.

Onwueme, I.C. 1978. The Tropical Tuber Crops. John Wiley and Sons. Chichester. 199-227.
Plucknett, D.L., R.S.D. Pena and F. obrero. 1970. Taro (Colocasia esculenta L). Field Crop Abstracts. 23(4): 413-426.

Rashid, M.M. 1993. Sabji Biggan (in Bengali). Bangla Academy, Dhaka, Bangladesh. 365.

Rashid, M.M. and Daunicht, H.J. 1979. Chemical composition of edible aroid of cultivar of Bangladesh. Scientia Horticulture, 10: 127-134.

Ruiz, L, Milian, J.O. Portieles, J.M. and Hernandez, P. 1989. Response of taro (Colocasisa esculenta L.) to nitrogen fertilizer on a red terralitic soil. Instituto Nacional de investigaciones en Viandas Tropicales. Santo, Dromingo, Villa, Clara, Cuba. 21(2): 67-73. 